\title{
Precise Location And Mapping Of The Main Central Thrust Zone In Referecne To Micro-Structures And Deformation Along Khudi- Tal Area Of Marsyangdi Valley
}

\author{
*Lokendra Pandeya ${ }^{1}$ *and Kabi Raj Paudyal ${ }^{2}$ \\ 1 Department of Mines and Geology, Lainchaur, Kathmandu, Nepal \\ 2 Central Department of Geology, Tribhuvan University, Kirtipur, Kathmandu, Nepal
}

\begin{abstract}
Geological mapping was carried out along Marsyangdi valley in the Khudi - Dahare -Tal area on a scale of 1: 50,000 covering about 142 square kilometers. Recent study aims to locate the Main Central Thrust (MCT) precisely based on lithostratigraphy, micro-structures, deformation, and metamorphism. Several thin sections were observed to study the metamorphism, deformation, and micro-structures developed in the rocks. The rocks sequences in both the Higher Himalaya and the Lesser Himalaya have undergone polyphase metamorphism and deformation. The Lesser Himalaya experienced first burial metamorphism (M1) followed by garnet grade inverted metamorphism related to the MCT activity (M2) followed by retrograde metamorphism (M3) whereas the Higher Himalaya has undergone regional high-pressure/ high-temperature kyanite/ sillimanite- grade prograde regional metamorphism (M1) followed by the (M2) related to ductile sharing which in turn is overprinted by the later post-tectonic retrograde garnet to chlorite grade metamorphism during exhumation. The polyphase deformation is indicated by the cross-cutting foliation and many other features. The deformation phase D1 is associated with the development of the bedding parallel foliation due to burial in both the Higher Himalaya and the Lesser Himalaya. Isoclinal folds and crenulation cleavage were developed before the collision is categorized as D2. Development of nearly N- S trending mineral and stretching lineation, south vergent drag folds, folded S2 cleavage and microscopic shear sense indicators, rotated syn- tectonic garnet grains, etc. were developed during the deformation D3 related to the ductile shearing through the MCT. Various brittle faults and shear zones cross-cutting all earlier features were developed during D4 during the upheaval. The rocks in the MCT zone are affected by intense sharing and mylonitization as indicated by the presence of many mylonitic structures in the thin sections throughout the Lesser Himalaya in the area. Features like polygonization and ribbon quartz with evidence of sub-grain rotation, mica fish, syn-tectonic rotated garnet grains indicate the ductile shearing in the MCT area suggesting the dynamic recrystallization in the MCT zone whereas rocks of the Higher Himalaya show the evidence of recrystallization under static condition. The MCT zone was mapped precisely based on the microstructures and deformation.
\end{abstract}

Keywords: MCT zone, petrography, micro-structures, metamorphism, deformation, Marsyangdi valley

Received: 14 March 2020

Accepted: 26 October 2020

\section{INTRODUCTION}

The present study area lies partly in the Lesser Himalaya and partly in the Higher Himalaya of central Nepal as shown in Fig. 1. Colchen, M., and P. Le Fort, 1980, distinguished broad tectonic zones of the area. A major structural discontinuity lies in the middle part of the area is MCT, location and definition of which has been a subject of great controversy. Classification of the rock strata and delineation of the MCT based on lithological as well as the microstructural difference is the subject of prime focus in the recent study. In the section, broad tectionic zones of the Colchen, M. P , Le Fort, 1980 can be further classified into different stratigraphic units. Attempts has been done for establishing the stratigraphy of Khudi- Dahare- Tal area of the Lamjung District by classifying the strata based on the adjoing section.

Paudel and Arita, 2000, carried out micro-structural analyses along the MCT zone in Kaligandaki River and Upreti, 2005

${ }^{\star}$ Corresponding author

Email Address: pandeya.lokengeo@gmail.com carried out micro-structural analyses along Modi Khola sections. Research related to microstructure around this section has yet to be studied, therefore an attempt has been made to observe deformation patterns especially in microstructures observed in microscopic petrographic section.

The present research aims in the delineation of the MCT, stratigraphic classification of the rock units, and to study the deformation style of the rock concerning the micro as well as mesoscale deformation structures in the Marshyangdi Valley section.

\section{METHODOLOGY}

Reconnaissance fieldwork was carried out to delineate the general affinity of the rocks. Following the reconnaissance fieldwork extensive field visit was carried out throughout the Khudi- Tal- Dahare area taking several traverses along valleys, road sections and foot trails to observe the lithostratigraphy, geological structures, and metamorphism of the area. Detailed columnar sections were prepared to observe the lithological 


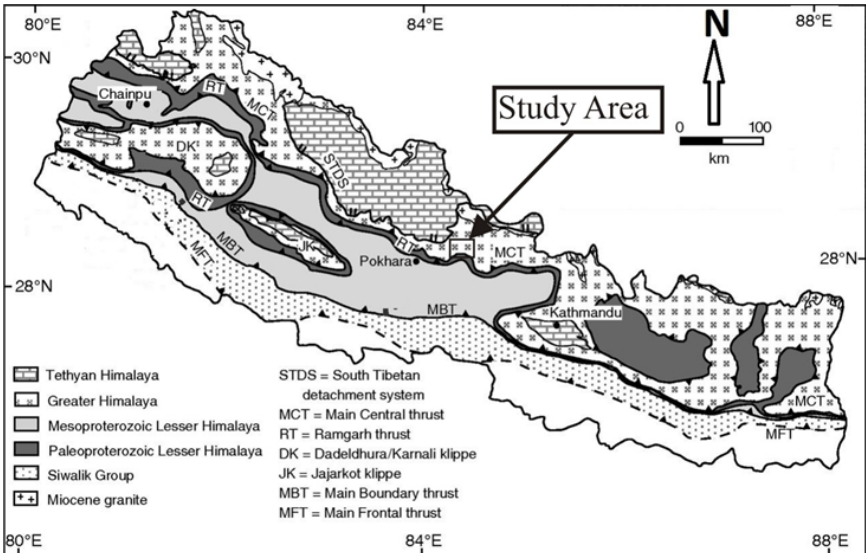

Fig. 1: Tectonic map of Nepal showing the Location of the Khudi- Tal area, Lamjung District(modified after Amatya and Jnawali 1994)

variation in the required section. Geological data were systematically recorded in the topographic base map of a 1 : 50,000 scale.

Strata were classified based on the lithological similarity and stratigraphic position following the stratigraphic codes. The geological map on the scale of 1: 50,000 was prepared along with relevant geological sections and the final copy of which was prepared after field verification. Several thin sections of systematically collected, fresh oriented representative samples including each lithological unit at different sections were prepared and studied for the identification of minerals and rocks, to find out equilibrium mineral assemblages, to study deformation pattern on mineral grains, type of grain contact, growth relationships, etc. Altogether, 45 thin-sections were studied for petrographic and microstructural analysis the location of the sampling sites is shown in Fig. 2.

\section{RESULTS}

\section{Lithostratigraphy}

Tectonically, the rocks of the region can be separated into two units; the Lesser Himalaya and the Higher Himalaya. Phyllites, pelitic and psammitic schists, quartzite, dolomitic marble, calc. schists are the main rock types of Lesser Himalayan Zone. Garnet to kyanite- sillimanite gneiss, two mica banded gneiss, quartzites, and Augen gneiss form the significant portion of the Higher Himalayan in the region.

The rocks of the Higher Himalaya are composed of high-grade metamorphic rocks. Tectonically these rocks are mapped north of the MCT. The Higher Himalaya is further divided into three units based on distinct lithology and association of minerals. From bottom to the top, these lithological units are Sillimanite -Kyanite gneiss, Banded gneiss and Quartzite, GarnetKyanite paragneiss. The generalized lithostratigraphy of the Higher Himalaya in the Marsyangdi valley section prepared after this study is shown in Figure 3. Geological boundaries are drawn based on the lithological similarity in different sections following the V's Rule. The geological map of the

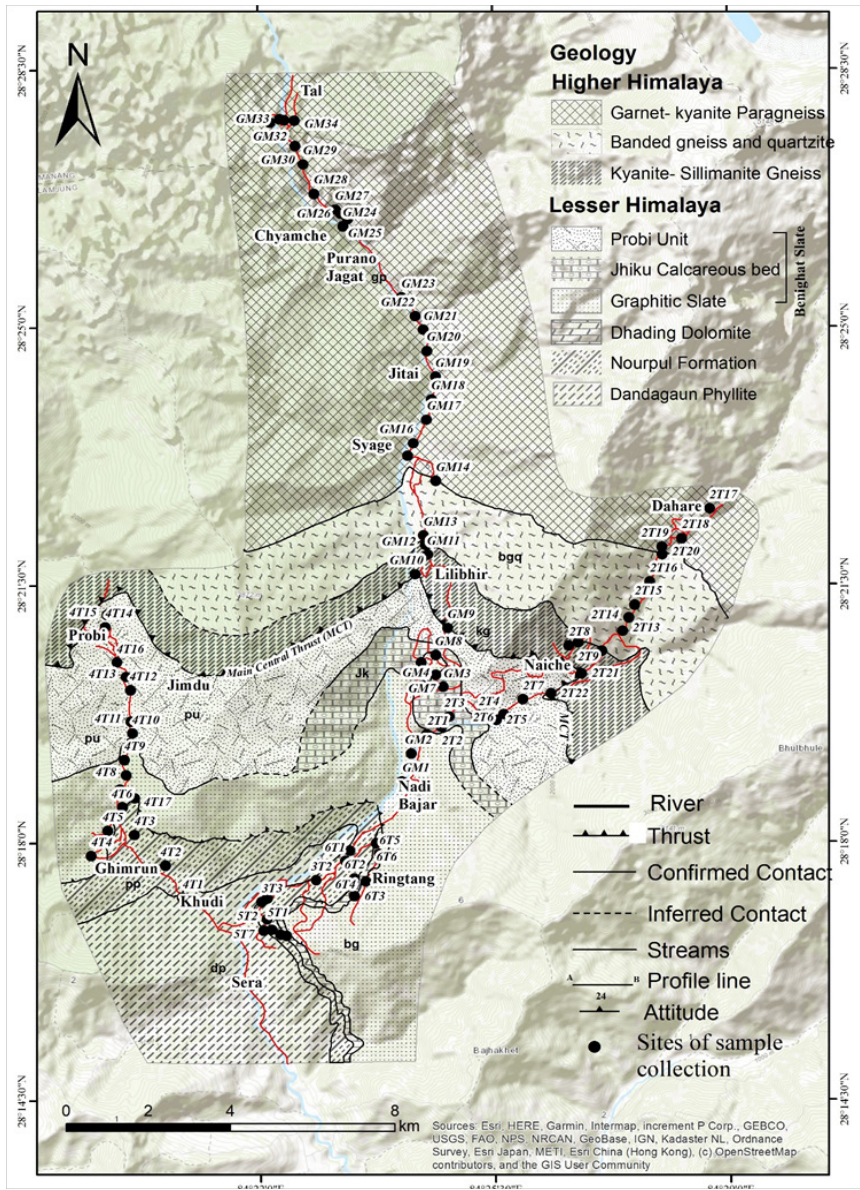

Fig. 2: Figure showing the location of sites of oriented rock samples.

Khudi-Dahare-Tal area is shown in a 1:50,000 scale is shown in Figure 4, in which MCT separates the Lesser Himalayan sequence from Higher Himalaya. The Lesser Himalaya in the present study area is delinated by the four lithological unit, equivalent to Dandagaon Phyllite, Nourpul Formation, Dhading Dolomite, and Benighat Slate of Lesser Himalaya in Central Nepal (Stöcklin and Bhattari, 1977) and (Stöcklin, 1980). The generalized lithostratigraphy of the Marshyangdi section is shown in Fig. 3.

The Dandagaon Phyllite is exposed at the southernmost part of the area around Simalchaur, Bandre, and Latephat area, and is comprised of light- grey, thinly- foliated phyllite to green-grey, thinly- foliated biotite- chlorite schist. The Nourpul Formation is well exposed at the Pallotari, Bhulbhule, Nandeswora, and western part of the Tranche village. The exposure consists of thick bands of white, thin- to medium- banded micaceous quartzite ( $50 \mathrm{~m}$ at the base) which is followed up section by the alteration of thin $(2 \mathrm{~mm}$ ) to thickly-banded (up to $30 \mathrm{~cm}$ ) micaceous white to bluish grey quartzite with light grey thinlyfoliated pelitic schist and dark grey garnet- biotite schist. The proportion and thickness of the pelitic and psammitic schist increases in the middle part of the succession whereas that of quartzite decreases. Garnet biotite schist is the major dominant lithology in the upper part with few quartzite intercalations. A dark-green, strongly-foliated actinolite-tremolite-schist is 
exposed at different structural levels within this formation. Dhading Dolomite in the study area is represented by thickband of gray to white dolomitic marble which is only exposed in the eastern part of the area on the way from Bulbhule to Bhusme and also near Taranche. Benighat Slate is extensively exposed around Bhusme, Rintan, East of Nadi Bajar in the eastern part and Ghimrun, Goptegaun and Sobje village in the western part of the study area where it forms extensive greengrey to dark grey thin to thickly- banded mostly coaly graphitic schist, dark grey pelitic phyllite to light to dark grey pelitic and psammitic schist.

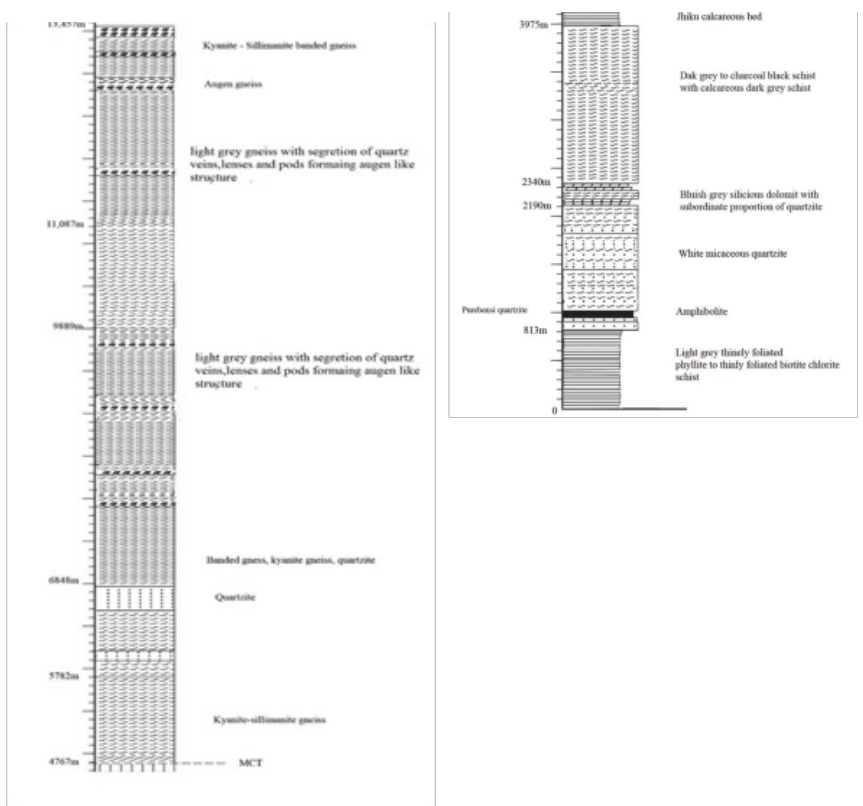

Fig. 3: Generalized Lithostratigraphy of the a) Higher Himalaya and b) Lesser Himalaya along Marsyangdi valley covering Khudi- Tal area.

\section{Geological structure and Deformation}

\section{Regional and Mesoscale structures}

The prominent regional scale structure in MCT. It separates relatively less metamorphosed rocks of Lesser Himalaya with the coarse-grained quartzite and gneiss of the Higher Himalaya. The Khudi- Dahare-Tal area is highly deformed. Regional to microscopic scale deformation features are abundant throughout the exposure including folds, faults, veins, mineral segregation pods, foliation, and lineations. A small scale cylindrical plunging fold named Bahundanda Anticline is observed near Bahundanda. Folds in the field range from tight isoclinal folds to drag folds ( Fig. 5). The fold axis of the isoclinal tight fold has a general trend of NNW -SSE is evident in Fig. 6, whereas the drag folds trend towards ESE-WNW the stereographic plot of which is displayed in Fig. 6.

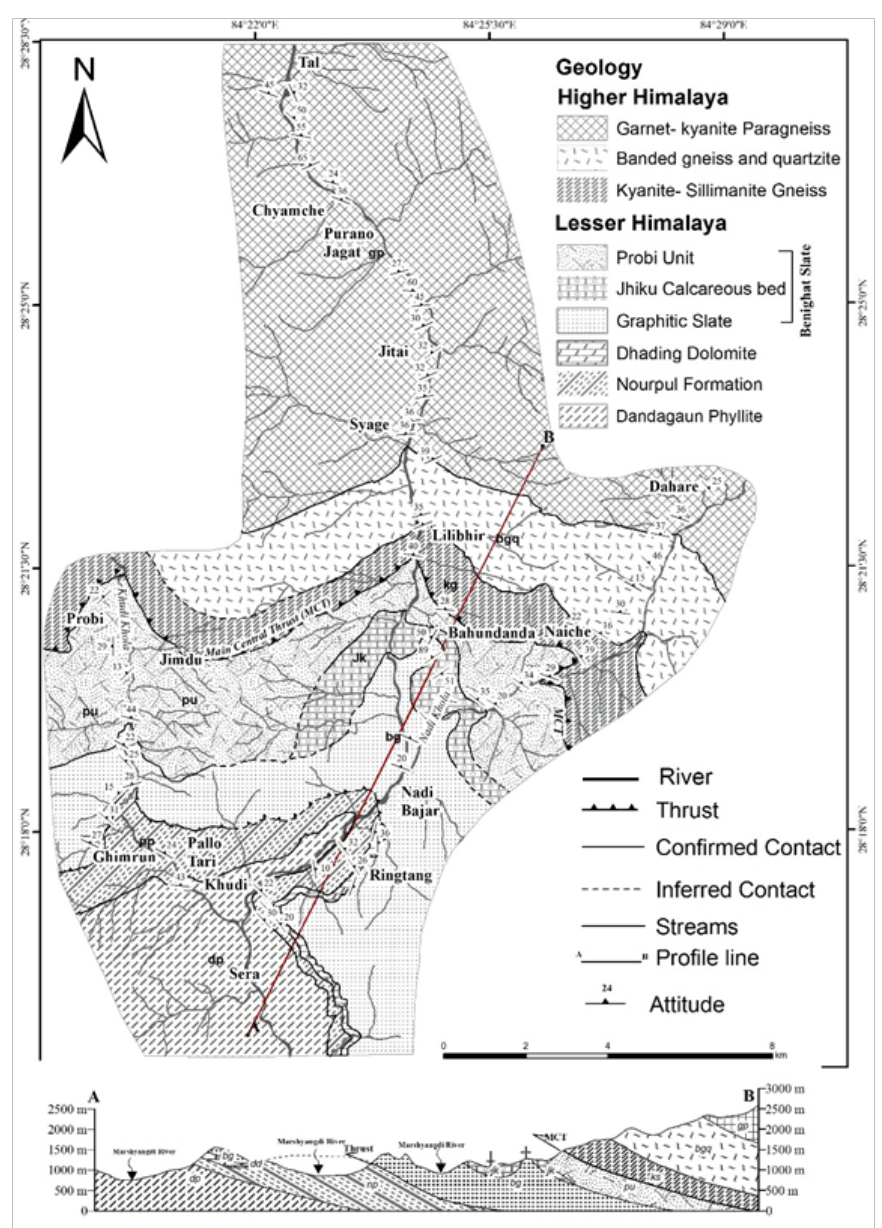

Fig. 4: Geological map and Cross-section of the Khudi- Tal area.

\section{Microstructures}

A wide range of microstructures is visible in the petrographic sections of various localities.

\section{Quartz grain microstructures in the Lesser Himalayan zone}

Quartz grain microstructures in the Lesser Himalaya show the significant variation in structures and mechanisms as moving towards the MCT. Quartz grains in the lower part of the study area have polygonal to amoeboid contact barely showing the evidence of polygonization but the flattening of quartz grain is seen in some thin sections from the area. Stratigraphically, higher sections, as shown in Fig. 7 (a), contacts of quartz grains are usually indented and some grains show undulose extinction, there is no evidence of polygonization and ribbon. Fig. 6 suggests the subgrain rotation recrystallization which is a dominant feature in the rocks of the Nourpul Formation. All relict grains have been completely recrystallized. The polygonized quartz grains are observed in many thin sections prepared in this zone. In the upper part of this formation, the 

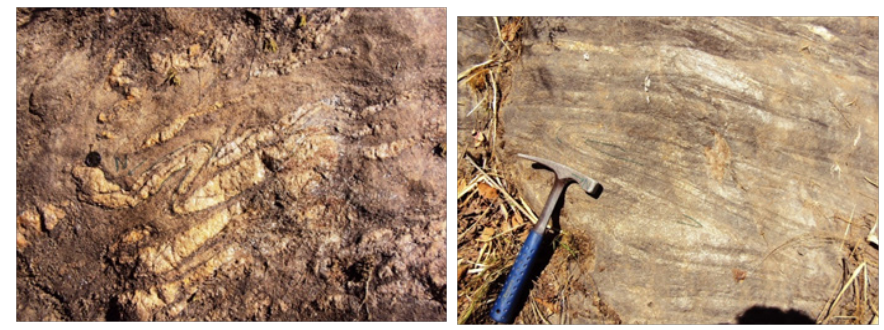

\section{Microstructure in the Higher Himalaya}

The quartz grains in The Higher Himalaya show straight and smoothly curved contacts which usually lack subgrains. Exaggerated grain growth contact between the adjacent grains is common as shown in Fig. 8 (a). Usually mica grains are included in quartz grains. Elongate strain-free crystals defining the foliation are common in most of the Higher Himalayan terrain. But in the thin sections prepared near to the MCT show the evidence of pressure solution as well (Fig. 8 c). But
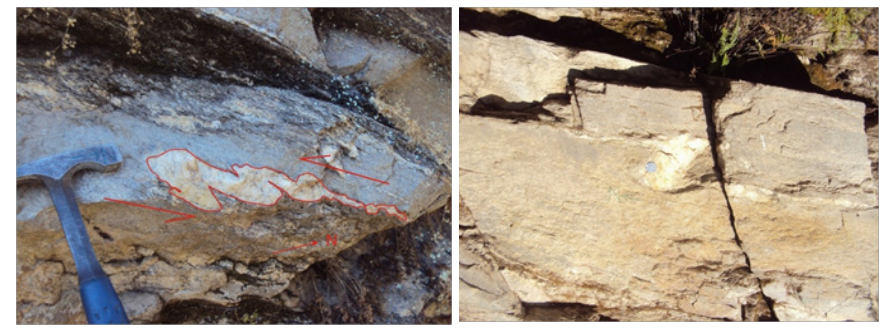

Fig. 5: Field photographs showing the exposure of a) z type drag fold observed in the Higher Himalaya, b) isoclinal folds observed in Higher Himalaya, c) pgtymatic folds observed in gneisses of the higher Himalaya, and d) asymmetric quartz boudin near MCT showing top to the south sense of shear.

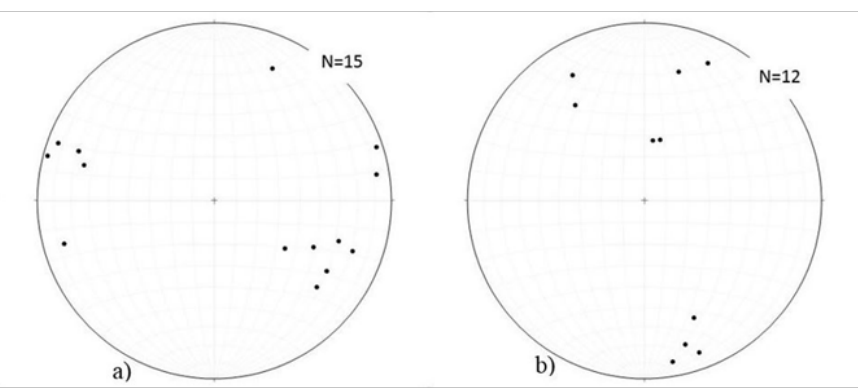

Fig. 6: showing stereographic (lower Hemispherical) projection of fold axes of (a) drag folds, b) of isoclinal folds observed in the present research area.

quartz grains are slightly flattened in the direction of foliation with triple grain boundary junction at places (Figure $7 \mathrm{c}$ ). As we move close to the MCT zone, polygonization is the prominent feature $\{$ Fig. 7 (d) Fig. 9 (c) $\}$. The quartz grain shows strong undulatory extension. Quartz grains are more prominently extended in the direction of foliation. Some quartz grains in this zone show top to the south sense of shear (Fig. 7d). In the vicinity of MCT, the middle and upper part of the Benighat Slate, the quartz grains are extended in the direction of foliation forming ribbon like structure of quartz with sweeping undulatory extinction. Polygonization and formation of ribbons of quartz are prominent suggesting dynamic recrystallization mechanisms (Fig. 7 e). In the uppermost unit of the Benighat slate, the quartz ribbon shows faint deformation lamellae as shown in Figure 7f. The ribbons are made up of strongly elongated polygonal quartz. Therefore, the quartz grain microstructures in the Lesser Himalayan zone show the dominant dynamic recrystallization and intracrystalline plasticity that increases in intensity as approaching the MCT.
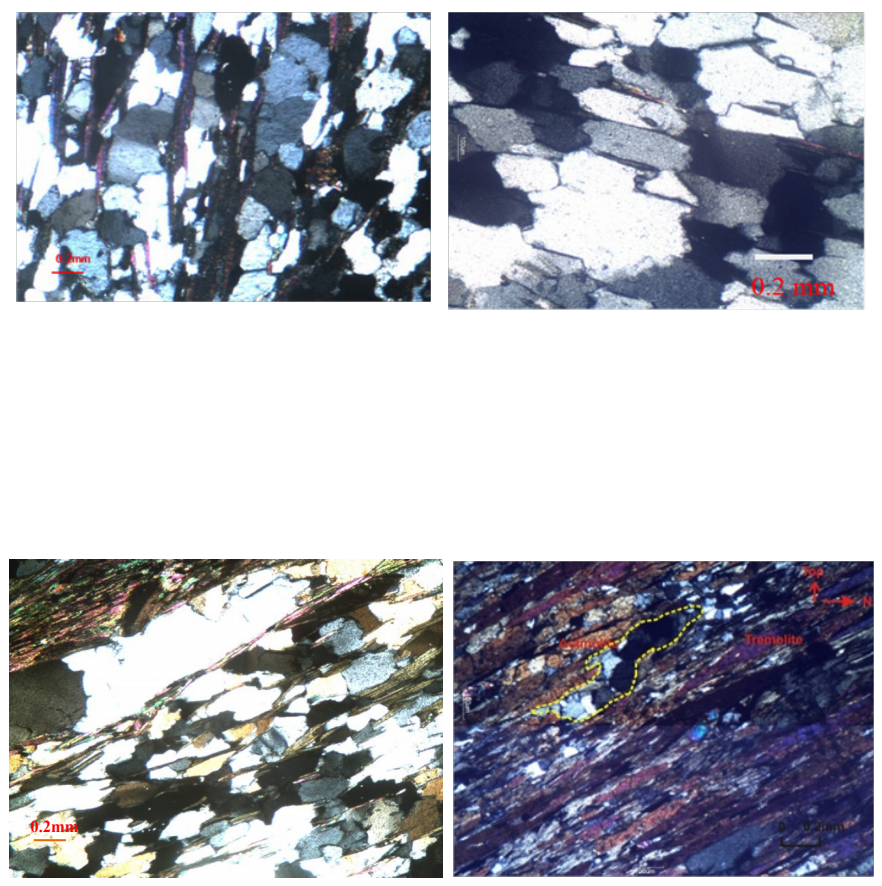

Fig. 7: Quartz grain microstructures from the MCT zone, the arrowhead points to the direction of decreasing structural distance from the MCT(UCN, 40x magnification):- a) Indented contacts, quartz grains show undulose extinction (sample taken from the Dandagaon Phyllite) 
b) Granoblastic texture of equigranular, polygonal, $0.1-0.2$ $\mathrm{mm}$ diameter, recrystallized quartz sub-grains, interpreted as evidence for subgrain rotation recrystallization c) quartz grains are slightly flattened in the direction of foliation; d) In actinolite schist quartz grains are polygonized, e) quartz grains showing ribbon texture with sweeping undulatory extinction from the middle part of the Benighat Slate;f) quartz grains in this photomicrograph show faint deformation lamellae with ribbon structure.
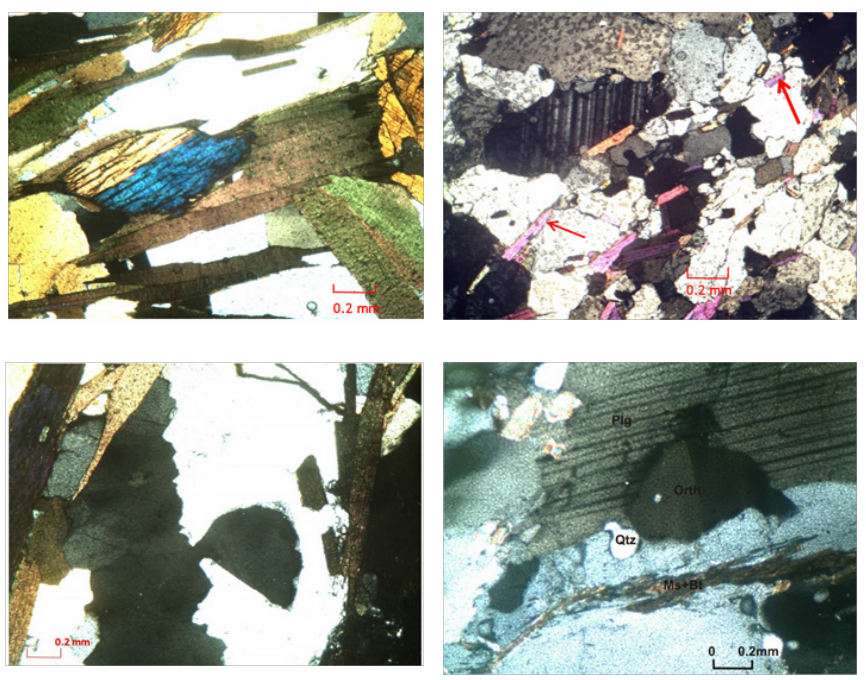

Fig. 8: Microstructures in the Higher Himalaya: (magnification $40 \mathrm{x}$, UCN) a) exaggerated grain growth contact between biotite, kyanite, and quartz grains. Note that the biotite grains are included in quartz in the lower central portion of the photomicrograph (location GM 10). b) Gneiss of the Higher Himalaya showing the indented contact shown by yellow arrow (pressure solution) between adjacent grains, muscovite grains are included in quartz and feldspar grains shown by a red arrow, c) Corrosive contact between quartz grains showing the evidence pressure solution near the MCT (Location GM 10, and d) Polysynthetic and Carlsbad twinning in plagioclase and orthoclase respectively GM 30 .

\section{Porphyroblast system and other microscopic features}

The porphyroblasts with the inclusion of other phases (poikiloblasts) are very useful for the interpretation of the tectonic evolution of the region. Garnet porphyroblasts with evidence of foliation wrapping the porphyroblast (posttectonic) to syn and post tectonic overgrowth of porphyroblasts containing inclusions of quartz in turn possessing truncated foliation are also evident (From Fig. 9 a to c) in microscopic sections.

Asymmetric quartz inclusions in the garnet grains (Fig. 9 (a) and Fig. 9 (b)), pressure shadow, and asymmetric polygonized quartz grains (Fig. 9 (d)) point to the top to the south sense of shear. The later one also indicates significant silica release form the metabasic rock due to metamorphic reaction. Microscopic chevron folds are seen in the hornblende - actinolite schist taken from the MCT zone. Kink bands are conspicuous in the thin section. Fig. 9 (e) displays only a portion of a fold. The folia of actinolite and tremolite define a fold but the individual folia is not strained or folded and each grain has uniform optical extinction. The folia was grown after folding indicating the post- tectonic growth.
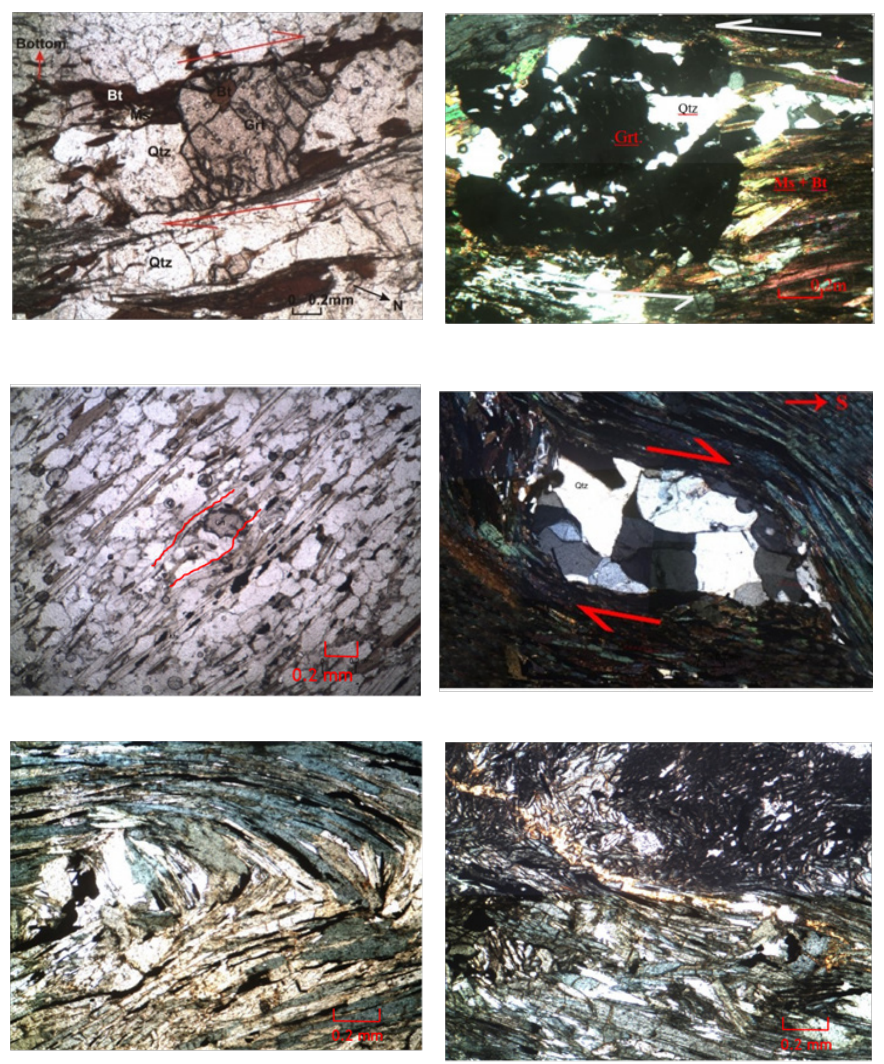

Fig. 9: Microphotographs a, c, e and f were taken under plane polarized light and remaining under cross Nicols a) Garnet grain with top to the south sense of shear, gneiss of the Higher Himalaya. b) S-shaped inclusion of quartz in garnet porphyroblast with truncated grains of mica at the sides indicating syn- tectonic origin c) Pre- tectonic garnet porphyroblast which is warped by the later developed foliation, strain shadow of quarts is also present, d) Asymmetric polygonized quartz grain showing the top to the south sense of shear in the actinolite schist, e) Microscopic chevron fold seen under the parallel polars in the sample taken from the actinolite schist of Nourpul Formation, f) Microscopic fold showing uniform optical extinction of actinolite and tremolite grains.

\section{Metamorphism and Deformation}

The strata of the Khudi-Dahare- Tal area is highly deformed and shows a high grade of metamorphism. Strata below the MCT are subjected to Garnet grade metamorphism whereas that in the Higher Himalaya are subjected to Kyanite and Sillimimanite grade of metamorphism. Metamorphic differentiation is common in the higher Himalayan terrain. Characteristic bandings of light and dark-colored minerals and zoned kyanite are examples of the metamorphic differentiation. 
Due to the metamorphic differentiation, various light and darkcolored bands are formed in the banded gneiss which represent the last stage of solid-state recrystallization and indicates an extreme condition of metamorphism. Mainly three facies of regional metamorphism is observed in Khudi- Dahare-Tal area, which are epidote- amphibolite facies, the amphibolite facies, and the granulite facies.

The terrain consists of shreds of evidence suggesting multiple episodes of mineral reactions -and recrystallization shown by cross-cutting relation between the mica flakes and the reaction rim of the biotite on garnet, and chlorite on biotite. Various growth sequences of minerals and fabric are observed in the thin section of both the Higher and the Lesser Himalayan terrain as shown in Figure 10. At least three phases of biotite growth are evident. Biotite flakes seem to be developed at successive stages of deformation and metamorphism as shown in Fig. 10.
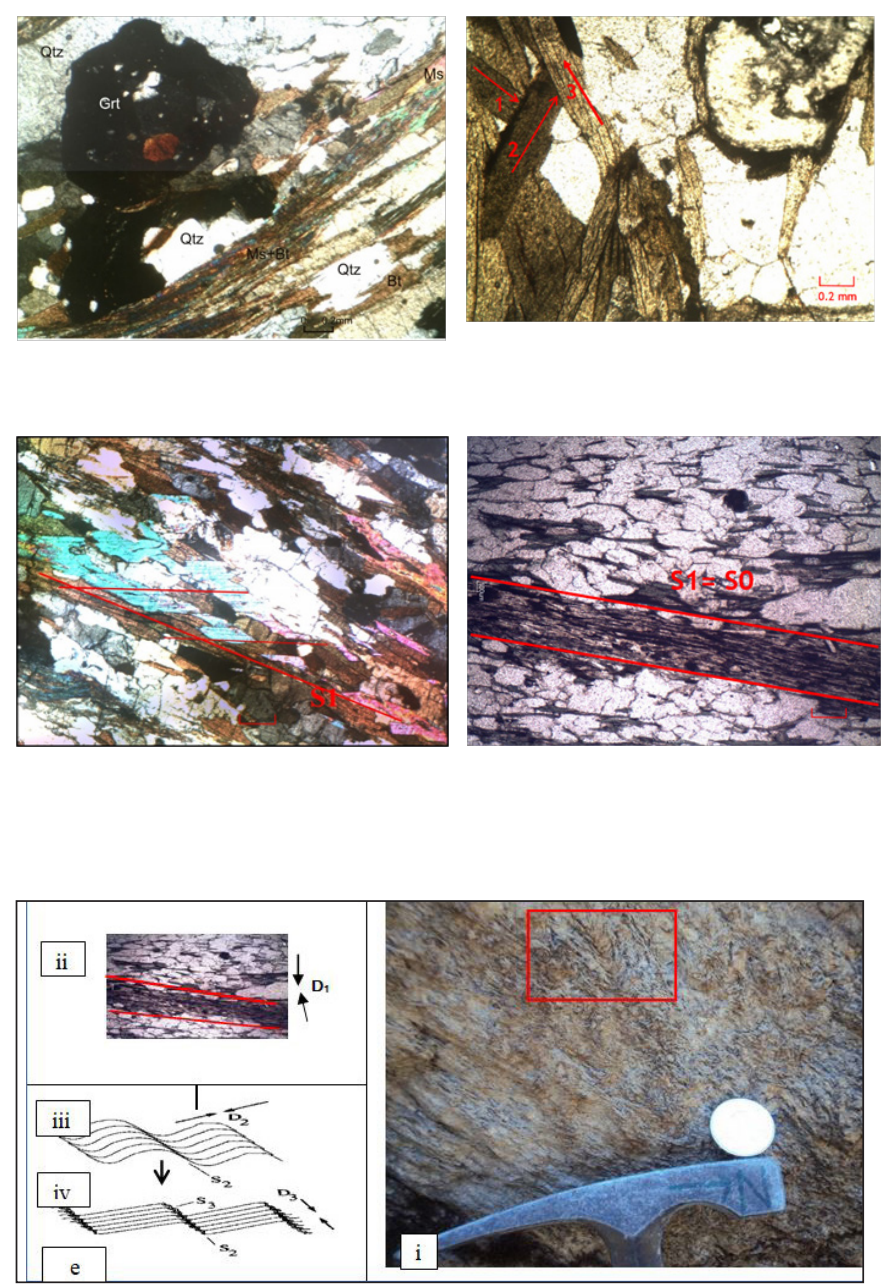

Fig. 10: Photomicrographs viewed under $\mathrm{CN}$ with 40x magnification( except Figure (d) which is taken UPPL), (a) retrograde alteration of garnet to biotite and biotite to chlorite, (b): Three phases of crystal growth is shown by the cross-cutting relation of biotite grains as shown by the arrow (location GM 13), (c) Two -sets of foliation, defined by the preferred orientation of mica minerals ( location
GM31)., (d) Micaceous quartzite with is the development of bedding parallel $\mathrm{S} 1$ foliation due to the burial of the rocks. This band represents the sedimentary layering so S1 $=\mathrm{S} 0$.e) Illustration of three deformation phases (i) shows the crenulation fold observed in the Higher Himalaya. The axis of the crenulation folds are also refolded, (ii) Figure showing development of bedding parallel S1 foliation due to the burial of the rocks, (iii) and (iv) shows the successive development of the S2 and S3 foliation.

\section{DISCUSSIONS}

The rock sequences in the Khudi - Dahare-Tal area belong to the two separate tectonic units separated by the MCT. The rocks of the MCT zone represent the Higher grade metamorphic equivalent of the rocks of the Nawakot Group. The rocks of Higher Himalaya in the present section are represented by paragneiss with various structures and mineral abundance with biotite content more than $30 \%$. Rocks of the HH probably belong to the Formation I of the Le Fort 1975. Further division of the unit is based on the dominant metamorphic mineral and fabric of the rock. The MCT zone has distinct lithological similarity with the Upper part of the Nawakot Group (Stöcklin and Bhattarai 1977; Stöcklin 1980) and is mappable in this section. Many published maps in this section are only the tectonic map. Therefore, at least four formations of the Stöcklin and Bhattarai (1977) and Stöcklin (1980) have been mapped in the present work. The established rock units presented are the metamorphic equivalent of the rock Units of Nawakot Complex. The four formations viz. Dandagaon Phyllite, Nourpul Formation, Dhading Dolomite in the present study section is mapped on a 1:50,000 scale.

Various mylonitic structures such as polygonization, pressure shadow, rotated quartz, and garnet porphyroblast indicate dominant dynamic recrystallization. The quartz in the MCT zone is in the form of elongated polygonal grains generally flattened to the direction of the foliation. The contact between the quartz grain is polygonal to amoeboid at the lower part whereas ribbon texture in the vicinity to the MCT. Some subgrains also show faint deformation lamellae and strong undulatory extinction. The ribbons are made up of strongly elongated polygonal quartz. Therefore the quartz grain microstructures in the MCT zone show the evidence for dynamic recrystallization and intracrystalline plasticity, the intensity of which increases as approaching the MCT. However in $\mathrm{HH}$, The quartz grains have straight or smoothly curved boundaries. Mica and other mineral grains are embedded in them and exaggerated grain growth are the common occurrence in the gneisses of the Higher Himalaya which all feature indicate the recrystallization under the static condition. However, some indented contacts and deformation lamellae indicate deformation under the dynamics condition. Therefore the rocks have undergone static recrystallization before MCT activity and later probably influenced little by deformation during MCT thrusting event. Therefore the quartz grain microstructures also support the sharp discordance along the Main Central Thrust. The concept and location of the MCT have been the topic of debates for a long time. The term 
was first introduced by Heim and Gansser (1939) in Kumaun Himalaya to separate the overlying higher-grade metamorphic rock as mica schists and gneisses with the lower carbonate autochthon. Valdia (1980) brought about the concept of two intracrustal thrusts, the Lower Munsiari Thrust (equivalent to the MCT of the Heim and Gansser) and Upper Vaikrita thrust. In Nepal French researchers such as Le Fort, 1975, Pecher, 1977 argue the existence of a single intracrustal thrust. Arita et al. (1982) and Arita (1983) describe the two intracrustal thrusts. He described that the upper Main Central Thrust is the tectonic Boundary separating the Higher Himalaya with the Lesser Himalaya. Some researchers place the MCT at the base of the first gneiss layer while others along a certain isograd, preferably at the base of the kyanite zone (Paudel 2000). The Main Central Thrust equivalent to MCT of Le Fort (1975) and Pecher (1975) and the MCT II of Arita et al. 1982 is a major structure in the present study area. It can be located by the distinct change in lithology, metamorphism, and deformation pattern in the Khudi- Dahare-Tal area.

\section{Deformation History}

Mapping and analysis of the major and minor structures were carried out in the Khudi- Tal area. Each rock sequences in the MCT zone and the Higher Himalayan zone has its deformation pattern and structural style. Folds of various sizes and styles, foliations of different generations, and various types of lineation are observed in different tectonic zones.

The Lesser Himalayan rocks experience first regional burial metamorphism, garnet grade inverted metamorphism followed by another retrograde metamorphism whereas the Higher Himalayan rocks experienced high pressure/high-temperature kyanite- sillimanite grade prograde regional metamorphism (M1) followed by the M2 related to large scale thrusting and shearing overprinted by the later Neohimalayan retrograde biotite to chlorite grade of metamorphism (M3) during the upheaval. Both the Higher and the Higher Himalaya experienced at least four phases of deformation.

\section{Higher Himalaya}

Higher Himalaya is affected by multiple phases of mineral growth. As seen in Figure 9 (b and c), at least three deformation phases can be observed. The fabric of the rock exhibit three different foliations, which are inferred to represent three, phase of deformation D1, D2 and D3 respectively. The field photographs of the crenulation fold with folded axis in Figure 9 (e) also indicates at least three phases of deformation. D1 produced a very good continuous cleavage which is penetrative, affecting the entire volume of the rock at the smallest scale. A second deformation produced the crenulation cleavage S2 nearly vertical. Finally, D3 folded S2 and producing another phase of crenulation D3 as interpreted in Figure 9 (ii to iv). The folds developed in the Higher Himalaya show its axis trending towards the west (Figure $5 \mathrm{~b}$ ). It means the folds were developed during the N-S collision in Himalaya. As the collision proceeded N-S, the folds were formed with axis trending towards E-W

\section{Lesser Himalaya}

The main central thrust zone also experienced at least three phases of deformation. Foliation Defined by the recrystallized quartz-rich and pelitic minerals rich layers is due to deformation $\mathrm{D} 1(\mathrm{~S} 0=\mathrm{S} 1)$. NNE -SSW trending mineral lineation in the Lesser Himalaya is developed due to the second phase of deformation D2 with top to the south sense of shear probably the syn to post MCT activity. the Last phase of deformation D3 is marked by the brittle deformation during the upheaval. lower hemispheric stereographic projection of the fold axis shows more or less N-S trends (Figure 5 a). These N-S trending folds were probably developed due to E-W compression. These folds were developed before the Himalayan Orogeny. Lineation in the rocks of both the Higher and Lesser Himalaya have to trend NNE to SSW and are the result of thrusting of $\mathrm{HH}$ from $\mathrm{N}$ to $\mathrm{S}$ that is syn-to Post MCT thrusting. The summary of the various deformation events and associated geological structures are summarized in Table 1.

Table 1: Summery table of Deoformation phases

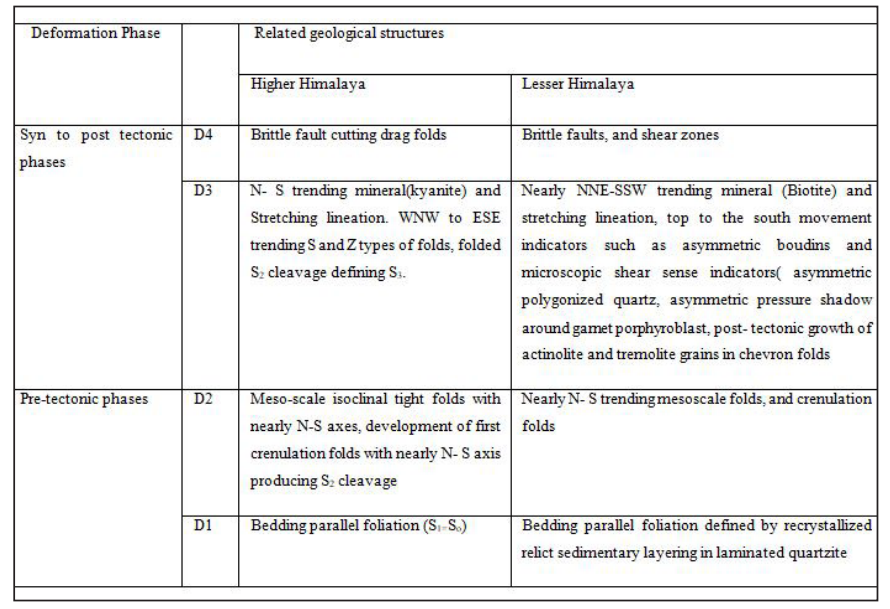

The Lesser Himalayan rocks experience first regional burial metamorphism, garnet grade inverted metamorphism followed by retrograde metamorphism whereas the Higher Himalayan rocks experienced high pressure/high-temperature kyanitesillimanite grade prograde regional metamorphism (M1) followed by the M2 related to large scale thrusting and shearing overprinted by the later Neo-himalayan retrograde biotite to chlorite grade of metamorphism (M3) during the upheaval. Both the Higher and the Higher Himalaya experienced at least four phases of deformation. 


\section{CONCLUSIONS}

The rocks succession of the Khudi-Tal area can be mapped under the two tectonic units i.e. the Lesser Himalaya and the Higher Himalaya. The Lesser Himalayan sequence can be further mapped into four rock units as the Dandagaun Phyllite, Nourpul Formation, Dhading Dolomite, and the Benighat Slate in stratigraphic upwards. However, the grade of metamorphism in these rocks is higher compared with the rocks exposed in their type sections in central Nepal. The higher grade of metamorphism is due to the presence of the MCT and other multiple shearing associated with the MCT zone. The rock succession of the Higher Himalayan consists of various types of paragneiss encompassing up to kyanite/sillimanite grade metamorphism. The MCT can be well demarcated and mapped in the Marshyangdi valley section. The field shreds of evidence like the change in lithology, metamorphic grade and, deformation style, etc indicate the presence of the MCT. Similarly, quartz grain microstructures also record different types of deformation patterns in the rocks of both the Lesser and the Higher Himalaya. Various microscale and mesoscale structures and shear sense indicators show the dominant top to the south sense of shear and the presence of a thick ductile shear zone around the MCT region. Petrographic studies of rocks show polyphase deformation, metamorphism, and mineral growth in the region.

\section{ACKNOWLEDGMENT}

The authors are thankful to the Central Department of Geology, Tribhuvan University, Kirtipur for providing the field equipment and laboratory facilities during this research. We are thankful to Subash Acharya, Niraj Singh Thakuri, Govind Pathak, and Sunu Dawadi for accompanying both in the field and thin section preparation. Thanks also go towards the local peoples of the Lamjung and Manang Districts who managed field accommodation.

\section{REFERENCES}

Colchen, M., P. Le Fort, and A. P., 1980. Carte géologique Annapurna-Manaslu-Ganesh, Himalaya du Népal, Cent. Nat. de la Rech. Sci., Paris.

Paudel, L. P. and Arita, K., 2000. Tectonic and polymetamorphic history of the Lesser Himalaya in central Nepal. Journal of Asian Earth Sciences. Pergamon, v. 18(5), pp. 561-584. doi: 10.1016/S1367-9120(99)00069-3.

Stöcklin, J., and K. D. B., 1977. Geology of the Kathmandu area and central Mahabharat range, Nepal. Nepal Department of Mines and Geology, Himalayan Report/ UNDP, (unpublished), $86 \mathrm{p}$.

Stöcklin, J., and Bhattarai, K. D., 1980. Geological map of Kathmandu area and central Mahabharat range. Sājediān Cartographic Company.
Upreti, B.N., and Yoshida, M., 2005. Geology and natural hazards along the Kaligandaki Valley, Nepal. Department of Geology, Tribhuvan University, p.122.

Heim, A. and Gansser, A., 1939. Central Himalaya, geological observations of the Swiss expedition 1936. Mémoires de la Société Helvétique des Sciences Naturelles 73, Zürich, 245p

Valdiya, K. S., 1980. Two intracrustal boundary thrusts of the Himalaya. Tectonophysics, v. 66, pp. 323-348.

Pêcher, A., 1977. Geology of the Nepal Himalaya: deformation and petrography in the Main Central Thrust Zone. In: Ecologie et Géologie de l'Himalaya, Colloques 222 Internationaux du Centre National de la Recherche Scientifique, Paris, v. 268, pp. 301-318.

Arita, K., 1983. Origin of the inverted metamorphism of the lower Himalayas, central Nepal. Tectonophysics, v. 95, pp. 4360. Auden, J.B., 1935. Traverses in the Himalaya. Records of the Geological Survey of India, v. 69, pp. 123-167.

Pêcher, A., 1977. Geology of the Nepal Himalaya: deformation and petrography in the Main Central Thrust Zone. In: Ecologie et Géologie de l'Himalaya, Colloques 222 Internationaux du Centre National de la Recherche Scientifique, Paris, v. 268, pp. 301-318. 